\title{
Improved Learning Design for Pre-Service Teacher in a Character Education Course
}

\author{
Sarkadi $^{1{ }^{* *},}$ Asep Rudi Casmana ${ }^{1}$, Yuli Rahmawati ${ }^{2}$ \\ ${ }^{1}$ Department of Pancasila and Citizenship Education, Faculty of Social Science, State University of Jakarta, Indonesia \\ ${ }^{2}$ Department of Chemistry, Faculty of Mathematics and Science, State University of Jakarta, Indonesia
}

Received October 16, 2019; Revised December 16, 2019; Accepted December 25, 2019

Copyright $(2020$ by authors, all rights reserved. Authors agree that this article remains permanently open access under the terms of the Creative Commons Attribution License 4.0 International License

\begin{abstract}
This study aimed to develop pre-service teachers' engagement in a character education course through new learning design of a RECE (Reflect, Engage, Collaborate and Elaborate) teaching model, in the Pancasila and Citizenship Education department of a university. RECE involve self-reflections and collaborative learning. The RECE active learning and teaching model was implemented to engage pre-service teachers in challenging classroom environments. The study was conducted with 65 pre-service teachers in their first year of study in a one semester character education course. Pre-service teachers in the study are prepared to become teachers of Pancasila and Citizenship lesson in high schools in Indonesia. The course aims to prepare pre-service teachers for future challenges they may have to deal with in relation to religion, nationalism, independence, working together, and integrity. This research used a qualitative method with the data collection of interviews, observations and document analysis. This research was divided into two phases: first, teaching model development and second, student engagement. The teaching model engaged pre-service teachers in current issues through collaboration and reflection. The results indicate that participants were motivated to engage in the course by reflecting on their learning, by using the higher-order thinking skills of critical and creative thinking, and by using collaboration and communication skills. The pre-service teachers were challenged to deliberate about critical issues and to solve problems that may impact positively on their role as future teachers.
\end{abstract}

Keywords Character Education, Teaching Model, Pre-Service Teachers, Pancasila and Citizenship Education

\section{Introduction}

Character education has become a critical issue in education in the face of a rapidly changing world. Character education aims to educate students to hold values that encourage them to live in a harmony with others and face challenges with integrity. The idea of character education has long been recognised by philosophers and researchers such as Aristoteles, Lickona, and Pietig. Lickona (1996) considers that character education is the most appropriate model to prepare future generations and school is the best place to develop young people's character (Lickona, 1996).

Curren (2016) claims that governments and education institutions need to pay serious attention to building character education because it helps develop human traits and behaviors that are important for the future (Curren, 2016). Philosopher and educator, John Dewey (Pietig, 1997) said that character embraces all purposes, desires and habits that affect human conduct, therefore, if people have good character they would also have habits that build peace and help them live in harmony. In support of this research, Licona's (1996) words align most closely to its purpose that to have a good character, at the very least, people need strength of mind, heart and will including the qualities of good judgement, honesty, empathy, caring, persistence, self-discipline and moral courage to be capable of work and love; two of the hall-marks of human maturity.

In the United States of America (USA), some public schools have a training development program for new students at the beginning of their first year of education where they learn good character traits (Williams, Yanchar, \& Jensen, 2003). In Japan, The Netherlands and The United Kingdom, governments have also implemented a character education model for students, which is similar to the USA model (Hiratsuka, 1980; Sanderse, 2013; Revell \& Arthur, 2007). Some schools have faced challenges in developing student character because classes focus on remembering lists of good values rather than focusing on challenging the values students hold. According to Hoon (2013), schools fail in teaching character education 
because they do not deal with relevant issues (Hoon, 2013; Pietig, 1997; Nurdin, 2015; Shields, 2011).

Teacher education in Indonesia faces challenges in developing the four prerequisite pre-service teachers' competences. Pedagogy, professional (content knowledge), social, and personal (Indonesian Law- UU Guru dan Dosen, 2015) competencies must be developed at pedagogical universities in addition to a new policy where teachers must complete a one-year professional development program, Pendidikan Profesi Guru (PPG) after graduation. These policies influence the way universities shape programs to enable pre-service teachers achieve the four competences and toprepare them for PPG.

In the research context, teacher education program in university is required to prepare pre-service teachers in certain subjects, such as Pancasila and Citizenship education. After graduation, and on completion of one year of professional development, pre-service teachers are expected to become Pancasila and Citizenship education teachers. The Pancasila's five principles (the belief in the one and only God, civilised humanity, the unity of Indonesia, democracy guided by the wisdom of the deliberations among representatives, and social justice of Indonesia) have an impact on societal values and practices, including the education system (Blackley, Rahmawati, Fitriani, Sheffield, \& Koul, 2018). Therefore, the study focused on this context, in addition to pre-service teachers play an important future role in educating and shaping young people's character and values.

A focus on mastering the facts of character education in university pedagogy which could influence the way future teachers deliver the content (Mohanty, 2015). Rather than shaping students' characters by challenging and developing their critical thinking, newly trained teachers might continue delivering the content as per the status quo. Therefore, the research project aimed to challenge students' higher-order thinking and creative thinking skills, and their collaboration and communication skills, by using online comment management to maintain hate-speech and fake news, to research, deliberate with others and communicate effectively.

Teaching character towards students would probably be considered to be difficult. Students will find boring during learning character in case they just listen to the teacher. Some countries have tried to develop some model to teach students about character. As such, this study will focus on developing some appropriate teaching model to educate character for university students, namely RECE teaching model. They are chosen because they will be a teacher either in junior high school or senior high school.

RECE teaching model stands for Reflection, Engagement, Collaboration, and Elaboration. The teaching model is used to answer the issue that learning character in the classroom gets boring (Rahmawati \& Taylor, 2012). Then, in the reflection stage, the preservice teachers as participants were asked to be given about current issues such as hoax news, diversity, hate speech and other issues
(Rahmawati \& Taylor, 2012). After reading the news, they are required to reflect what they get in classroom. The pre-service teachers also need to collaborate and engage with other participants in the classroom, so that learning about character will be beneficial for them (Rahmawati \& Ridwan, 2017).

The RECE teaching model is not the only one practice that can develop good character for the students. There are a wide range of researches which focusing on developing students' character. However, there are three main reasons why RECE teaching model can be successful to be applied. Firstly, the participants are pre-service teachers, in which they are university students who are designed to be a teacher in school. They are not only learning about the character values in the classroom, but also discussing about how to teach traits for their future students. In addition to this, collaborative learning is part of the teaching model which can create students to discuss and interact with other students in classroom (Rahmawati \& Taylor, 2012). As such, this model can probably reduce boring in classroom. Finally, after the teacher understanding how RECE teaching model works, it can be applied towards their future students in school.

The character or people's behaviour is considered to be difficult to be seen or observed. It is also difficult to measure whether it is a good or bad character. This situation can be the limitation of this study. However, there are several researches which state that every country has the standard of character, including Indonesia. The government, by which Ministry of Education and Culture, Republic of Indonesia is trying to classify the character of Indonesian, and it is stated by the rule. The Indonesian government number 87 in 2017 about strengthening character education. It is stated that there are a lot of character that can be an example of Indonesian citizens, such as religious, cooperation, integrity, being independent and others. All of these characters can be part of Indonesian character.

Based on the background and problems regarding character education, the research questions for this study are: How the effectiveness of RECE model in teaching character education course for pre-service teachers? How the challenges of pre-service teachers while engaging in RECE teaching model?

\section{Literature Review}

\subsection{Character Education}

Some experts argue that character is a measurement of people, especially regarding their attitude and personality, and that character is something that can be seen in peoples' behaviour which can be percieved as either bad or good (Agboola \& Tsai, 2012; Carr, 2016; Lopes, Oliveira, Reed, \& Gable, 2013; Vaccarezza \& Niccoli, 2018). Therefore, character is understood to be a state that has been established through a long process from childhood to 
adulthood. Character education is an issue not only in Indonesia but also across the world and, as a result, some countries are trying to build their nations by implementing character education in their schools (Turan \& Ulutas, 2016; Kisby, 2017; Tutkun, Görgüt, \& Erdemir, 2017; Park, 2017; Anggraini \& Kusniarti, 2016). In Turkey, some teachers use storybooksto teachcharacter education. These teachers report that students respond positively to a storybook because they can see how good characters behaveas well as being interested in how the teacher tells the story (Turan \& Ulutas, 2016). University is one place where character education can be taught, and pre-service teachers are required to learn the values of characters. It is because after they graduate from the pedagogy university, they will come to school and be a teacher in that education institution. As such, it it is important to understand how to teach character education in higher education institutions(Park, 2017; Leavy, 2016; Phelps, 1993).

Character education is implemented into schools with purpose often aligns to a government's intention that their citizens can be good people and have a positive impact on their society (Muscott, O'Brien, \& College, 1999). Democratic governments want citizens to participate in society and contribute to political activity by critiquing government policy. In the USA, Schaeffer (1999) points outthat character education is a long-term educational goal intended to create good citizens by developing skills such as knowingand caring about neighbours, and having compassionand respect for others. In many societies, where working parentshave little time to have meaningful conversations with their children, schools need to take responsibility for teaching character that can then be applied in the classroom and outside the school environment(Vessels \& Boyd, 1996; Schaeffer, 1999; Skaggs \& Bodenhorn, 2006; Lickona, 1997). Teachers can share their real-life experiences,as part of a character education program,to show how a good citizen responds(Chiu, et al., 2018).

Another main goal of implementing character education is to help students develop future goals (Dishon \& Goodman, 2017) related to the skills they need to have after graduation. In this context, pre-service teachers are expected to have skills such as higher order thinking skills, creativity, collaboration and communication skills (Hoon, 2017). Therefore, in order to develop these skills, students need to be encouraged and motivated to complete their education in a timely manner. Teachers should model the importance of having study goals(Riesman, 1967; Stiff-Williams, 2010)

Lee (2014) argues that by learning character education at school, all students will be expected to develop meaningful skills such as caring for others, valuing courage, cooperation, respect, responsibility and honesty(Lee, 2014). Theseskills can be taught in several ways. Hollingshead (2009) suggests creating a character education training program for first-year students at university to help them question their mindset and set a new goalfor the
future(Hollingshead, 2009). Using teaching methodsthat incorporate activities such as drama and dialogue can also motivate students and influence their mind(Krajewski, 1999; Mathers, 1995).

Indonesia society is based on the five principles of Pancasila which describe the main characteristics of Indonesian citizens. These principles are the core values by which Indonesian people live. One of the principles of Pancasila is humanity and social justice need to be strengthened in support of Lichona (1996) who claims that one of the purposes of teaching character education is to create an environment where people can live in harmony. As such, character education needs to be directly implemented into schools. In Indonesia, character education can be taught in many ways and varied according to the age of the students(Novianti, 2017; Meidl \& Meidl, 2013; Risnawati, 2017). At university level, Novianti (2017) taught her students using Buildungromans, or coming-of-age novels. She argues that Buildungromans can educate readers as they read the stories. While schools play an important role in character development, Rasyad (2015) argues that character education is not only the responsibility of the schools but, parents are also responsible for creating children of good character (Rasyad, 2015).

\subsection{Pre-Service Teacher Education}

Teachers play an important role in society because they are required not only to transfer knowledge, but also to incorporate character values during their teaching. Transferring knowledge means teachers only convey the content knowledge, such as math, sociology, geography, politics and other content knowledge without any character during learning. In addition to this, some teachers are also required to give motivation regarding character values such as honesty, tolerance, living in harmony and other character values during learning. However, it is the challenges for teacher education program to empower their pre-service teachers, not only for delivering knowledge, but also for shaping their characters(Glanzer, Ream, \& Talbert, 2003). A pre-service teacher can be defined as a person who is being prepared to educate students at school (Nguyen \& Yang, 2018; Juuti, Christophersen, Elstad, Solhaug, \& Turmo, 2018; Reid \& Reid, 2017; Manning, 1912). Each country uses different systems and methods to create better teachers for the future. These education systems fulful the require of many governments that their citizens receive a high quality education.

Scandinavian countiries are often held up as an example of what a quality education system looks like. In Finland, for example, teachers must hold a masters degree from reputable higher education institution (Juuti, Christophersen, Elstad, Solhaug, \& Turmo, 2018). In Canada, content knowledge plays an important role in shaping teachers competences since a sharp fall in math score among students forcedpedagogical universities toput 
additional effort into preparing their mathematics pre-service teachers (Reid \& Reid, 2017). Therefore, as professional educators, pre-service teachers should demonstrate mastery in both pedagogical and content knowledge. In Indonesia, pre-service teachers are trained at a pedagogical university,within different subject areas, to earn a degree in education (Zein, 2016). After graduation, they are required to join a one year professional development program (Program Profesi Guru-PPG) and pass the certification process to be teachers. This new policy was implemented to improve teacher quality. Indonesia teachers must achieve proficiency in professional (content), pedagogic, personal, and social competences (Law of Teacher and Lecturer Number. 14, 2005). These competences are an obligation for graduates in the teacher education program.

In this research, character education course is being part of the courses for preparing Pancasila and Citizenship Education teachers. The students who are enrolled to department of Pancasila and Citizenship Education will take this course as part of their study. In the context, of this research, the course of character education is required to develop the pre-service teachers' competences in character development, society values, nationalism, personality, environmental awareness, responsibility and integrity. After students graduated from the university, they will became a teacher of Pancasila and Citizenship Education course. Pancasila and Citizenship Education part of curriculum subject in schools in Indonesia. The research was focused in the character education unit course in the department of Pancasila and Citizenship Education. The course plays important role as fundamental knowledge and skills for pre-service teachers of Pancasila and Citizenship. In addition to their future role as teachers who educate character of young generations. Therefore, the learning experiences should be created in contextual teaching and learning which empower students to critical analyse and solve the challenging problems. In addition to their important role in helping develop students' character and the Pancasila and citizenship values in relation to their competences. The character education course is part of compulsory in the department and it takes two credit semesters which aims for empowering pre-service teachers in character education and understanding their roles in shaping character of their future students.

The research focused on student engagement as an interaction, communication, motivation, and teachers' efforts to transfer the knowledge to their students. Students' engagement can be in the form of students' feedback, student's representation, and students approach to learning (Dragseth, 2019). As part of improving the quality of learning and engaging students' learning, teachers should always encourage students to learn for achieving course learning outcomes. In classroom engagement, teacher and student has meaningful interactions within enthusiastic classroom, therefore students show their comprehension through questions, critical listening, and arguing (Furrer, Skinner, \& Pitzer, 2014). In the classroom, students are expected to develop their higher order thinking skills throughout meaningful learning experiences.

\section{Method}

\subsection{Research Design}

The method used in this research was qualitative. This method was used to explore how students' engagement in character education course using RECE teaching model. Students' engagement in the study focusing on students' learning motivation, knowledge, value and character development which are course aims. This qualitative research method also could answer why and how the pre-service teachers develop their skills using RECE teaching model (Cohen, Manion, \& Morrison, 2007). Students' engagement in the study focusing on students' learning motivation, knowledge, value, and character development which are course aims.

\subsection{Participants}

The participants in this research were 65 pre-service teachers from Department of Pancasila and Citizenship Education, Pedagogical University in Jakarta, Indonesia. Students from Pancasila and Citizenship Education department will be Bachelor of Education and they will be the Pancasila and Citizenship Education teachers in school. They were all registered students in the second year in department of Pancasila and Citizenship Education. The character education unit course is one of the compulsory units for citizenship education pre-service teachers for one semester with 2 credits (50 minutes contact hours) which delivers in even semester for 16 meetings. Total minimum credits for graduation is 144 credits which consists of politic, law and state knowledge, and pedagogy knowledge.

\subsection{Data Collection}

The data collection process was divided into three main parts, which were semi-structured interviews, a focus group discussion, reflective journal, and fieldnotes about some values of character education. At the first glance, the pre-service teachers who attended the character education course in the university were interviewed and the culture of class was observed by researcher. In the implementation phase, the first researcher gathered the data using reflective journals and fieldnotes. Finally, in the post implementation phase, the first researcher collected the data through semi-structured interviews and pre-service perception about character education. The reflective journal consisted of information on what was happening, how student' 
respond in the classroom, and also their opinion regarding some learning activities as well as their experience. During the fieldnote, the observation was undertaken on how RECE teaching model was conducted in character education course and also how pre-service teachers' responses. In observation stage, the written description was recorded by the first researcher, while the other two researchers were acted as observers. Open-ended questions were used to conduct semi-structured interview regarding student's feeling of reflect, engage, collaborate and elaborate on character education course. The length of interview was about 15-20 minutes and it was recorded using voice recorder. Higher order thinking skill was assessed when they get a lot of sources and reflect their ideas.

In addition, the data collection process were carried out using Bahasa Indonesia with focusing students' learning experience using RECE teaching model, then the data presentation was translated into English for the purpose of publication. The RECE teaching model used in this study was developed in English version. It takes participants through each stage of reflect, elaborate, collaborate, and engage. Pre-service teachers as participants explained each stage name in English language, then explaining the process in Bahasa Indonesia

\subsection{Data Analysis}

In order to analyze the data, it is used several methods. Firstly, the interview results were recorded and analyzed using nVIVO software(Cohen, Manion, \& Morrison, 2007; Miles \& Huberman, 1994). During the interview, the language used was Bahasa Indonesia, and then it is translated into English. Then it is transcribed into text and put it into nVivo software (Cohen, Manion, \& Morrison, 2007). This software helps to analyze to be easier, so that the coding was generated to analyze the results. The expert opinion about character education and teaching model was used to clarify the results.

When it comes to the FGD (focus group discussion), the RECE teaching model was applied towards some experts prior to use it for pre-service teachers. The participants who were attending the focus group discussion were lecturer from Pancasila and Citizenship education department, lecturers who teach character education, and other lectures relating to teaching citizenship studies. The results of the FGD were agreed that the RECE teaching model was suitable and it can be used for teaching in university students. During the FGD, there were a wide range of revision, development and improvement, so that the model was developed through the appropriate way for teaching.

During the fieldnote and reflective journal, it was taken during the learning process where RECE teaching model was applied towards pre-service teachers. It was undertaken to see whether the lecturer argue that the RECE teaching model was the right model or not. At the end, after the observation, the lecture could share towards other teachers.

Finally, to see the trustworthiness of this research, the overall results were validated by the content experts, language experts and education experts. It was intended to make sure that the models which will be used and applied towards pre-service teachers were advance.

\section{Findings}

The study results showed that character teaching education is challenging when exploring pre-service teachers' values. The RECE teaching model was implemented as a step to help understand pre-service teacher thinking when faced with dilemmas where they must solve problems and express opinions. The participants' engagement was demonstrated by their motivation to learn, and by reflecting on their values, developing their higher order thinking skills of critical and creative thinking, and by starting to learn to communicate and collaborate with others. The findings are discussed below.

\subsection{The Effectiveness of RECE Model in Teaching Character Education Course for Pre-Service Teachers?}

The teaching model covers four main stages where a literature review and reflection on teaching experiences, as teacher educators, is followed by designing the teaching model. Experts then validated the model and provided feedback. The final stage was implementation of the model.

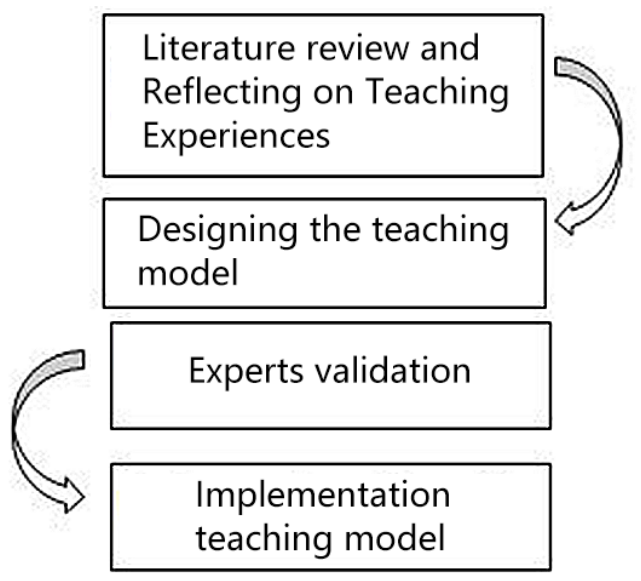

Figure 1. Teaching model development

The teaching model consists of four stages of Reflections, Engagement, Collaboration, and Elaboration. The concepts of constructivism, character and values education, higher order thinking skills, and reflections were also explored throughout the process of implementation 


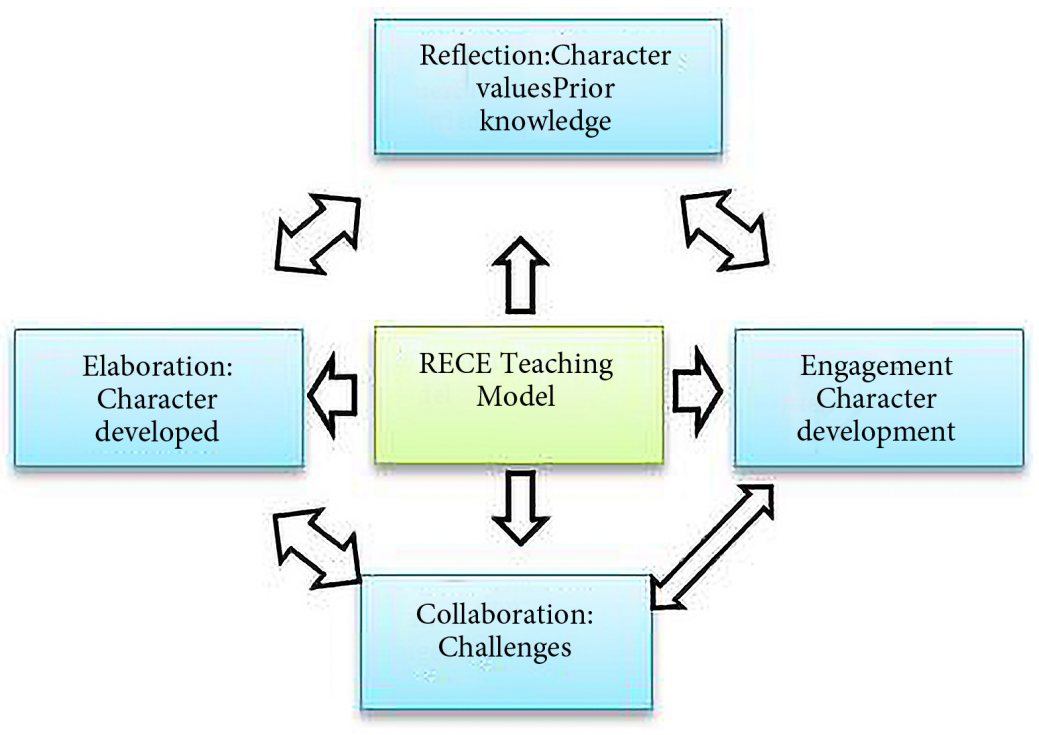

Figure 2. RECE Teaching model

\begin{tabular}{|c|l|}
\hline Steps & \multicolumn{1}{c|}{ Descriptions } \\
\hline Reflection & $\begin{array}{l}\text { Pre-service teachers reflect on their values using a dilemma case study related to hate speech and hoax news which is a } \\
\text { current issue on social media. In this step, pre-service teachers are asked their opinions and what actions they might take } \\
\text { about a current situation. They need to put their position to someone who believes in the hate speech and hoax news. In this } \\
\text { step students work individually as they reflect on their own values and character. }\end{array}$ \\
\hline Engagement & $\begin{array}{l}\text { At this stage, pre-service teachers think critically about their opinion of the case and extend their thinking by searching } \\
\text { through different learning resources (such as articles, research, books) to justify and enrich their opinion. }\end{array}$ \\
\hline Collaboration & $\begin{array}{l}\text { In the third stage, pre-service teachers are assigned to work collaboratively in solving the problems. In this step, the } \\
\text { students need to decide on a solution as group decision by presenting their own ideas and justifying them based on the } \\
\text { different resources they found during the engagement phase. }\end{array}$ \\
\hline Elaboration & $\begin{array}{l}\text { At the end of the program, the lecturer discusses the pre-service teachers' decisions and their relation to the character } \\
\text { education topics that are taught. At this stage, the pre-service teachers elaborate on their discussion results in alignment } \\
\text { with the lecturer's explanation. Judgment is made on how they reflect and justify their own values. }\end{array}$ \\
\hline
\end{tabular}

The learning steps are designed for students to reflect on their own values, then transforming throughout the learning process.

Using RECE teaching model, the students argue that it was a new method which can transform their knowledge. It is because RECE teaching model ask the pre-service teachers to think critically and collaborate with other students during learning process. For instance, students were asked to read a lot of book, news and journal to make them understand that having critical thinking skill is one of the ways to be the best teachers. As such, this RECE teaching model can be one of the effective teaching models to teach character education for pre-service teachers.

\subsection{The Challenges of Pre-Service Teachers While Engaging with RECE Teaching Model}

The participants' conceptual understanding in character education course was elicited through the questioning and reading a bounce of reference as well as current issues during the learning process using RECE teaching model which was then strengthened by using in-depth interviews and observation. Based on the results during the process, several participants are able to communicate and collaborate with other students in classroom. In addition, some pre-service teachers have a higher order thinking skill that they have learned during character education course. This section would discuss some students' motivation, value reflection, higher order thinking skill and collaboration as well as communication.

\subsubsection{Motivation}

Pre-service teacher motivation to learn is important as they will need to engage in and understand the concept of character development which will influence their competency as teachers. As first-year university students, they are in a stage of transition from being secondary school students who are used to learning within a teacher-centered approach to a more active learning environment. They think that their learning experiences of memorizing content will continue in university as they consider that as pre-service teachers, they will need to understand content knowledge. During their transition to university, they need to develop confidence in their competences as university students (Van Rooij, 2018). Expressing their own thinking when solving problems does not commonly happened during learning activities and students become comfortable as passive learners (Rahmawati \& Taylor, 2012). The following participant's statement portrays their motivation to find out different 
issues and resources.

During the course, the approach has stimulated me to know more about the issues, I used to learn about good and bad values, but not to reflect on my own. (Student 3)

Pre-service teachers were engaged in justifying their opinions by looking at different resources. They looked eager to understand the problem through discussion. (Observation)

The data show that pre-service teachers were engaged with a real case related to their daily lives. The interview results show that at the beginning of the course, the students are encouraged to learn about how to differentiate the good news and bad news. This is intended to make them think that having a lot of sources is a better than just believing towards only one news. For instance, pre-service teachers are suggested not only read one online news such as The Jakarta Post, Kompas.com, Republika, BBC News, but they are required to read all the news regarding one isues. Reading a wide range of news or receiving plenty of sources would make them engage in justifying their opinion.

\subsubsection{Values Reflections}

Value reflections have been stimulated by encouraging the participants to reflect on their existing values to help understand their character. A case study stimulated them to understand the context of issues relevant to their daily lives. Participants reported that they sometimes believed in hoax news that looked real. According to El Rayess, Chebl, Mhanna, Hage (2017), hoax news often appears in credible sources which drives people to believe it and share it across multiple social media platforms (Rayess, Chebl, Mhanna, \& Hage, 2018). Participants gave an example of how relationships can break down because people might hold a strong believe in the hoax news and don't want to accept that others don't believe it. This issue has become a serious problem in Indonesia as 2019 is an election year where a presidential election will be held between two competing candidates. People found sharing hate speech on their social media can be jailed (The Jakarta Post, 2019). A participant shared the following experience:

I realized that when I believe hoax news and strongly believe it, made me not want to lose when I argued with others. People we call "netizens", state the hate speech which also influenced other's opinions, and caused worse opinions to spread. (Student 1)

This example shows that participants learnt to express their experiences in dealing with the case study. Student 1 shared his previous values when dealing with the issues, as an example of the initial step in character development, by reflecting on values and experiences. However, not many participants showed they valued reflection, therefore this phase of the RECE process in character development was challenging within passive learners situation. The lecturer tried to develop a good relationship with the research participants prior to challenging their thinking. According to Rahmawati and Ridwan, (2017), teachers need to develop positive teacher-student relationships in order to empower their students. At the end of the lesson, the lecturer related the students' experiences to existing society values and their relationship to course aims. The following participant statement reported on the role of the lecturer.

During learning, the lecturer asked me to read the case study and reflect on my own values. It was interesting for me because I realised the case was relevant to my own experiences. The lecturer always encouraged us to speak without being afraid of being wrong.(Student 5)

Based on this statement, the participant recognized the lecturer's role in facilitate their learning, especially in learning speak up about their values. At this stage of the RECE process, the participants came up with a wide range of opinions based on their prior knowledge and experiences. They argued that it is important to appreciate others, to think critically, and to accept the differences. Dilemma based case studies can stimulate students to reflect on their values (Rahmawati \& Taylor, 2013) and can help them develop their characterby challenging their critical and creative thinking skills.

\subsubsection{Higher Order Thinking Skills}

The higher order thinking skills used in this research were critical and creative thinking which were stimulated through the use of a challenging case where participants were required to make decisions. In the engagement step, participants were asked to explore different resources to justify their decisions. It means that students need to prepare their future life. For instance, what career will they choose after graduation, what company that they will create in the future, or what life that they become years ahead. They came to the understanding that, as pre-service teachers, they will deliver information to students that should be based on sound knowledge. The case which was used to make participantsthink critically was about hate speech and hoax news where they had to identify different perspectives. Misinformation and rumours can spread quickly across countries by using social media such as Facebook or the Whatsapp application. While social media has some positive impacts such as connecting people, it can also facilitate the spread of unreliable news (Reuters, 2019).

The RECE teaching model addresses hoax news so that students understand the need to check the reliability of the content before sharing. For example, participants were introduced to political commentary through current news articles, a YouTube video, and many other sources of information that helped students to think critically before they shared the news using their social media profiles. Participants were expected not to accept the news or information right away beforecross checking it with other sources. In their research interviews participants reported on the challenges of thinking critically. 
When I understand the case, I need to take the best decision. The options really made me confused, so that I needed to ask someone with experience by, reading a Google review, and watching a YouTube video in order to get the best option. I had never done research like this before when I want to make a decision. In this classroom, I learn so much about evaluate my thinking (Student 5)

The interview with the participants showed that critical thinking was developed during the learning process. Rather than making snap decisions, they needed to undertake some research in advance. This result supports Shpeizer's(2018) view that critical thinking is an emerging skill due to the number of choices people are faced with today and students need to be taughthow to choose the best option. Furthermore, Huber \& Kuncel (2015) consider that critical skills are so necessary that they need to be taught in higher education institutions. However, they go on to argue that some colleges do not know on how to teach critical skillsat a university level(Huber \& Kuncel, 2015).

Research participants reported that the learning experiences challenged them in developing their creative thinking skills, especially in finding alternative ways to solve the given problems. They also learned to express their voice critically which was different from their previous learning experiences. Research by Rahmawati and Koul (2016) indicates that students in lower secondary school in Australia also face experiences where they don't have many opportunities to express their voice in classroom activities. The RECE teaching model challenged participants to think differently, as the statement below indicates:

The case that lecturers gave challenged my thinking, I chose my own opinion, however through searching and discussion in a group, I found different ways that a solution can be explored (Student 10)

Interview analysis shows that students engaged in developing their creative thinking skills through self-reflection and social learning in discussion with others. Chinese and Indonesian scholars support this outcome by revealing that focus group discussion can be a place to teach critical thinking (Solihati \& Hikmat, 2018; Wang \& Seepho, 2017). Creative thinking skills are considered to be an essential2 $1^{\text {st }}$ century skill which needs to be taught to students (Thompson, 2017). In their future role as teachers, participants understood that they also need to train their students in developing these thinking skills:

As a future teacher, I realized becoming teacher is not only transferring the knowledge, developing their character, but also to challenge the emerging student mind in order to make them think critically. It is not an easy task, but it is very challenging for me, especially as a Pancasila and Citizenship Education teacher (Trainer interview)

Participant reflections on their future role as teachers will help them to develop their future life throughout the process of the teacher education program. The Pancasila and Citizenship Education teacher plays an important role in developing students' character in the Indonesia education system. Therefore, it is important for them to self-reflect and continually developed their professional competences including their higher order thinking skills.

\subsubsection{Collaboration and Communication Skills}

Collaboration and communication skills are required competences to live in $21^{\text {st }}$ century, especially in an era of borderless information transfer and connection. Thinking collaboratively means that pre-service teachers should be able work in a group to solve problems. The RECE model was shaped to challenge students to collaborate with others to solve problems. At this stage in the model, participants shared their own opinions and worked collaboratively to come up with group decisions. They were asked to identify people'sbehaviour on social media. The following statement from a pre-service teacher participant highlights the challenges faced during the collaboration phase:

I am a new university student, and I don't know my classmates and the lecturer very well. However, group work forced me to work with others and solve the problems together. We have different ideas but we have to come out with one decision.(Student 3)

Participants learnt to communicate with others, especially when they had different opinions, as they needed to develop empathetic communication. In addition, they also had to present their group results which required them to use public speaking skills.

I have some difficulty in public speaking. This is my first experience in presenting group discussion results in front of other students. I was worried about being asked questions by other students.(pre-service teacher reflective journal, student 5)

These two students showed that communication skills are very important and should be taught to first year students (Huber \& Kuncel, 2015). As future teachers, education students need to learn how to communicate effectively and confidently whilst appreciating different opinions. Pre-service teacher engagement, through the RECE teaching model, challenged them with different learning experiences. This first experience was expected to help shape the pre-service teacher's character as well as stimulate their think about their future role in educating their own students' character.

Overall, the model has challenged students' thinking system and paradigm as passive learners. Therefore some students still disengaged with learning experiences which was created. Expressing ideas and active participation has disempowered some students in their learning. Therefore, it is important for the lecturer to engage students in comfortable learning experiences to express their ideas and thinking process.

\section{Discussions and Implications}

The findings of this study revealed that RECE teaching 
model which has been used to teach character education has improved the pre-service teachers' engagement in classroom. Although there are several limitations, at least the RECE model has contributions and this can be used by other teachers which intend to educate character education. Based on the aim of this research, the pre-service teacher's engagement would be divided into four main goals, which are improving the students or preservice teachers' motivation, value development, increasing higher order thinking skill, and communication as well as collaboration skill.

At the first stage, the pre-service teachers have a low motivation to be the teachers, because they do not know on how to educate students at schools. The school subject which will they teach is PPKn or Pancasila and Citizenship Education. This is caused by a lot of reasons, such as too much knowledge load, limited time to teach in a week, and limited teachers' resources. This issue is not only happened in Indonesia, as several countries are experiencing the same problem when they teach citizenship education at the school (Arthur \& Wright, 2013; Asgharzadeh \& Nazim, 2017; Bates, 2012). The participants argue that they will get the knowledge by memorising the sentences or books, as this is their preliminary knowledge before getting in touch with the course. However, after six months learning character education at the university by using RECE teaching model, they understand that character cannot be taught by memorising the words. It should be taught by reading the case from the news and discussed with peer in classroom on how to solve this issue. They are presented with the issues about character in campus such as hoax news, truancy, smoking in campus, bribery and other negative behaviour (Arthur J. , 2008; Auciello, 2006). As such, this teaching model helps improve students' motivation to be a teacher for the future. This is the successful goal of teaching character in the campus for pre-service teachers.

During the first stage of RECE teaching model, which is reflection, the students were taught about the learning motivation in university. They are encouraged to have a lot of sources to study, and they should not memorise some words or sentences like when they were in high school level. Some participants said that during character education course, they are given some good news and bad news and they should analyse to get the right option. In reflection stage, they should have a lot of resources, so that they can easily recognise and justify by themselves.

In addition, pre-service value reflection is considered to be important. It is because pre-service teachers should probably be able to reflect their knowledge after reading and consuming several books, and news from the journal or some articles. Based on research studies, value reflection can appear when students have a wide range of sources (Rahmawati \& Taylor, 2012). In this research, after the interview, pre-service teachers were taught not only discussion in the classroom, but also they are required to read a lot of news and books prior getting in to the classroom. As a results, they come up with a bunch of knowledge, and they should reflect their values at the classroom to share the knowledge to their friends. One of the participants also said that they are not afraid of presenting wrong on the classroom because they are encouraged by the lectures.

Using RECE teaching model, during engagement process, students should be able to reflect their own values after reading a lot of books, journal and news. This allows them to have their recognition and their own opinion. Some participants said that during the learning in character education course, students can obtain the new knowledge and values not only from the books and news, but also they can conclude based on themselves.

Higher order thinking skill is imperative for $21^{\text {st }}$ century teaching skills. Some experts argue that this is because the students in school get a bunch of resources from the internet and it should be sorted out by several technique (Arthur \& Wright, 2013; Arthur J. , 2008). As teachers task are not only delivering the knowledge, teachers are also required to help students develop their thinking skill (Chiu, et al., 2018). Therefore, as part of teaching character education, pre-service teachers should equiped with higher order thinking skills. During one semester, the participants on this research are taught by several case study. They are presented with the issues in every meeting, so that the pre-service teachers were getting used to think critically when they faced the news. The teaching model encouraged students to understand that fake news are always everywhere, therefore they should be able to sort this out.

Finally, communication and collaboration are the skills which should be owned by the students. This skills enable teachers to deliver the knowldege and insight smoothly to the students (Lickona, 1996). During the interview and observation, the pre-service teachers were equiped with the communication skill. They should present in the classroom after discussion. They also has debate with their friends in classroom with the current issues in the country. As such, communication skill uncounsciously develop during learning in character education course. In observation, collabocation and elaboration were developed at the end of the stage. The participants can ellaborate what they get from the news, books, and journal to be in their opinion and it can be implemented when they become a teacher after graduation from pedagogical university.

The RECE teaching model overall have several implication in education. Firstly, this teaching method can be used to educate character or behaviour either for citizenship education teachers, or other social science teachers. It can also be used in some level of educations, such as junior high school and senior high school. The teaching model can also develop students to have a critical thinking skills, because it help students to get a wide range of resources from various references such as books, news, journals and other reference. Therefore, it helps students in 
school to have some critical thinking and collaboration skills.

However, there are also some limitation which might occur from the results of this research. This RECE teaching model is considered to new, and it just examided in department of Pancasila and Citizenship Education. Firstly, it cannot generalised and it might not work for some other pre-service teachers since the participants is not enough. Hawthrone effect might be occure during observattion and students can realize that they are under reseach (Cohen, Manion, \& Morrison, 2007). Further reseach about character education especially in the university need to be undertaken to understand more about RECE teaching model.

\section{Conclusions}

Character education is an important element of education for the younger generations, because it is design to shape what people should be done for their daily life. Since character education considered to be critical, there is a need to develop pre-service teachers' competences, especially in those who are responsible for teaching Pancasila and Citizenship education. Through this research, the RECE teaching model engaged the pre-service teacher participants in personal and social learning through self-reflection and collaboration. After undertaking the research, it can be concluded that RECE teaching model is one of effective ways for teaching character in pre-service education teacher, although there are a lot of ways or methods to teach character. However, there are also some challenges to teach character education.

RECE teaching model is developed into four main stages to teach character for pre-service teacher in university. At the first stage, in reflection stage, pre-service teachers are not only getting the knowledge about the issues which is currently happening, but also they are asked to reflect it in front of the classroom. This means that they should share what they read in front of other pre-service teachers. After that, as the second stage is elaboration, the pre-service teachers should be able to elaborate and collaborate with others. What they are doing in this stage is that they share their ideas towards others. The value that they can learn in this stage is collaborative skill as this is needed in $21^{\text {st }}$ century ability (Ridwan, Rahmawati, \& Hadinugrahaningsih, 2017). In addition, as the pre-service teachers would develop the skill, it can also be shared towards their future student in schools.

An important stage that contributed to character development was the reflection stage where pre-service teachers reflected on their values. Successful implementation of the RECE model requires a comfortable learning environment and a positive relationship between lecturer and pre-service teacher to be developed so that values can be shared honestly. The lecturer needs to understand the characteristics of pre-service teachers' that influence their values and thinking.

After successfully developing RECE teaching model, there are some advantages for pre-service teachers that is beneficial for the future. Firstly, pre-service teachers will probably gain higher order thinking skill as this the need of $21^{\text {st }}$ century teaching skill (Ridwan, Rahmawati, \& Hadinugrahaningsih, 2017). The skill will directly go to the pre-service teachers because in the reflection stage, they read a wide range of article and news about the current issue. Secondly, the pre-service teachers are also learn about collaboration and communication skill, as this skill is developed when they reflect and share what they read in classroom. The collaboration and communication skill is part of $21^{\text {st }}$ century essential skill which students should have during this age. As such, RECE teaching model could help them to learn the skill.

Finally, pre-service teachers also learn about motivation, and values reflection. As first-year university students, they needed to adjust to new learning environments which required a shift from passive to active learning. In addition, participants needed to reflect on their future role as teachers and be empowered to continuously develop their competences. These sorts of advantages will be the way to address the challenge of teaching character education

Although it seems that RECE teaching model is effective and has a lot of advantages to teach character, it also has some limitation. Further research is needed to develop each part of the skill in RECE teaching model. What is more, other approaches will be also possible for teaching character education.

\section{Acknowledgement}

We are very grateful to experts for their appropriate and constructive suggestions to improve this template.

\section{REFERENCES}

[1] Agboola, A., \& Tsai, K. C. (2012). Bring Character Education into Classroom. European Journal of Educational Research, 1(2), 163-170.

[2] Anggraini, P., \& Kusniarti, T. (2016). The Implementation of Character Education Model Based on Empowerment Theatre for Primary School Students. Journal of Education and Practice, 7(1), 26-29.

[3] Arthur, J. (2008). Traditional Approaches to Character Education in Britain and America. In L. P. Nucci, \& D. Narvaez, Handbook of Moral and Character Education (pp. 80-98). New York and London: Routledge.

[4] Arthur, J., \& Wright, D. (2013). Teaching citizenship in the secondary school. Routledge. CITY?

[5] Asgharzadeh, A., \& Nazim, Z. (2017). The Enlightenment 
conceptions of pedagogy and global citizenship education: A Canadian case study. Education, Citizenship and Social Justice, 00(0), 1-4. Retrieved from http://journals.sagepub. com/doi/10.1177/1746197917731276

[6] Auciello, J. (2006). Teaching for Character: Education for English Teachers. The Journal of Education, 187(3), 57-69.

[7] Bates, R. (2012). Is global citizenship possible, and can international schools provide it? Journal of Research in International Education, 11(3), 262 -274. Retrieved from https://doi.org/10.1177/1475240912461884

[8] Blackley, S., Rahmawati, Y., Fitriani, E., Sheffield, R., \& Koul, R. (2018). Using a Makerspace approach to engage Indonesian primary students with STEM. Issues in Educational Research, 28(1), 8-42.

[9] Carr, d. (2016). Virtue and Character in Higher Education. British Journal of Educational Studies, 1-16. Retrieved from http://dx.doi.org/10.1080/00071005.2016.1224806

[10] Chiu, F.-C., Hsu, C.-C., Lin, Y.-N., Liu, C.-H., Chen, H.-C., \& Lin, C.-H. (2018). Effects of Creative Thinking and Its Personality Determinants on Negative Emotion Regulation. Psychological Reports, 122(3), 1-28.

[11] Cohen, L., Manion, L., \& Morrison, K. (2007). Research methods in education ( 7 th edition). Routledge.

[12] Curren, R. (2016). Aristotelian versus virtue ethical character education. Journal of Moral Education, 1-11. Retrieved from http://dx.doi.org/10.1080/03057240.2016.1 238820

[13] Dishon, G., \& Goodman, J. F. (2017). No-excuse for character: A Critique of Character Education in no-excuses Charter School. Theory and Research in Education, 15(2), 182-201.

[14] Furrer, C., Skinner, E., \& Pitzer, J. (2014). The influence of teacher and peer relationships on students' classroom engagement and everyday resilience. In David Shernoff and Janine Bempechat (pp.101-123), NSSE Yearbook Edition: Engaging Youth in Schools: Evidence-Based Models to Guide Future Innovations. Colombia University: Teachers College Record

[15] Glanzer, P., Ream, T., \& Talbert, T. (2003). Why Both Classical and Modern Character Education Are Not Enough: Lessons from The Emperor's Club. Journal of Education and Christian Belief, 7(2), 103-112.

[16] Hiratsuka, M. (1980). Moral Education in Japan. Journal of Moral Education, 10(1), 53-80. Retrieved fromhttp://dx.do i.org/10.1080/0305724800100107

[17] Hollingshead, B. (2009). Adoption Model: A Framework for Examining Implementation of a Character Education Program. NASSP Bulletin, 93(3), 166-183.

[18] Hoon, C.-Y. (2013). Multicultural citizenship education in Indonesia: The case of a Chinese Christian school. Journal of Southeast Asian Studies, 44(3), 490-510.

[19] Hoon, C.-Y. (2017). Putting Religion into Multiculturalism: Conceptualising Religious Multiculturalism in Indonesia. Asian Studies Review, 41(3), 1-18.

[20] Huber, C. R., \& Kuncel, N. R. (2015). Does College Teach Critical Thinking? A Meta-Analysis. Review of
Educational Research, 20(10), 1-38.doi:10.3102/00346543 15605917

[21] Juuti, K., Christophersen, K.-A., Elstad, E., Solhaug, T., \& Turmo, A. (2018). Finnish teacher education and its contributions to pre-service teachers' instructional self-efficacy. Issues in Educational Research, 28(2), 422-436.

[22] Kisby, B. (2017). Politics is ethics done in public': Exploring Linkages and Disjunctions between Citizenship Education and Character Education in England. Journal of Social Science Education, 16(3), 7-20. doi: 10.2390/jsse-v $16-\mathrm{i} 3-1582$

[23] Krajewski, B. (1999). Enhanching Character Education through Experiential Drama and Dialogue. NASSP Bulletin, 83(609), 40-45.

[24] Leavy, B. (2016). Effective leadership today - character not just competence. Strategy and leadership, 44(1), 20-29.

[25] Lee, A. (2014). Implementing character education program through music and integrated activities in early childhood settings in Taiwan. International Journal of Music Education, 34(3), 1-12. Retrieved from https://doi.org/10.1 $177 / 0255761414563195$

[26] Lickona, T. (1996). Eleven Principles of Effective Character Education. Journal of Moral Education, 25(1), 92-100. doi:http://dx.doi.org/10.1080/0305724960250110

[27] Lickona, T. (1997). The Teacher's Role in Character Education. Journal of Education, 179(2), 63-80.

[28] Lopes, J., Oliveira, C., Reed, L., \& Gable, R. (2013). Character Education in Portugal. Childhood Education, 89(5), 286-289.

[29] Manning, A. C. (1912). Character Building. Gallaudet University Press.

[30] Mathers, K. (1995). Values-The Beginning of Character Education. NASSP Bulletin, 79(572), 116-118.

[31] Meidl, C., \& Meidl, T. (2013). Character education in three schools: Catholic, Quaker and public. International Journal of Primary, Elementary and Early Yers Education, 41(2), 178-187.

[32] Miles, M., \& Huberman, A. M. (1992). Analisis Data Kualitatif: Buku Sumber Tantang Metode-Metode Baru. Jakarta: UI Press.

[33] Mohanty, A. (2015). Information Processing and Creative Thinking Abilities of Residential and Non-Residential School Children: A Pilot Study. SAGE Open, 1-12.

[34] Muscott, H. S., O'Brien, S. T., \& College, R. (1999). Teaching Character Education to Students with Behavioral and Learning Disabilities through Mentoring Relationships. Education and Treatment of Children, 22(3), 373-390.

[35] Nguyen, H. M., \& Yang, H. (2018). Learning to become a teacher in Australia: a study of pre-service teachers' identity development. The Australian Educational Researcher, 625645 .

[36] Novianti, N. (2017). Teaching Character Education to College Students Using Bildungsromans. International Journal of Instruction, 10(4), 255-172. 
[37] Nurdin, E. S. (2015). The Policies on Civic Education in Developing National Character in Indonesia. International Education Studies, 8(8), 199-209. Retrieved from https://d oi.org/10.5539/ies.v8n8p199

[38] Park, S. Y. (2017). Clarifying the Characteristics and Exploring the Collaboration of Citizenship and Character Education in South Korea. Journal of Social Science Education, 16(3).

[39] Phelps, P. H. (1993). Challenge of Building Character. Taylor \& Francis, Ltd

[40] Pietig, J. (1997). John Dewey and Character Education. Journal of Moral Education, 6(3), 170-180. Retrieved from http://dx.doi.org/10.1080/0305724770060304

[41] Rahmawati, Y., \& Koul, R. (2016). Fieldwork, co-teaching and co-generative dialogue in lower secondary school environmental science. Issues in Educational Research, 26(1), 147-164.

[42] Rahmawati, Y., \& Ridwan, A. (2017). Empowering students' chemistry learning: The integration of ethnochemistry in culturally responsive teaching. Chemistry: Bulgarian Journal of Science Education, 26(6), 813-830.

[43] Rahmawati, Y., \& Taylor, E. (2013). Dilemma story teaching in science learning: A promise for developing students' soft skillsthrough critical thinking and deep learning. International Seminar on Mathematics, Science, and Computer Science Education (pp. 56-75). Bandung: Universitas Pendidikan Indonesia.

[44] Rahmawati, Y., \& Taylor, P. C. (2012). Revealing and reconceptualising teaching identity through the landscapes of culture, religion, transformative learning, and sustainability education: A transformation journey of a science educator (Doctoral dissertation, Curtin University).

[45] Rasyad, A. (2015). Developing a Parenting Training Model of Character Education for Young Learners from Poor Families by Using Transformative Learning Approach. International Education Studies, 8(8).

[46] Rayess, M. E., Chebl, C., Mhanna, J., \& Hage, R.-M. (2018). Fake news judgement The case of undergraduate students at Notre Dame University-Louaize, Lebanon. Reference Services, 46(1), 146-149. Retrieved from https://doi.org/10 .1108/RSR-07-2017-0027

[47] Reid, M., \& Reid, S. (2017). Learning to be a Math Teacher: What Knowledge is Essential? International Electronic Journal of Elementary Education, 9(4), 851-872.

[48] Reuters. (2019, January 22). Facebook's WhatsApp limits users to five text forwards to curb rumors. Retrieved from The Jakarta Post: https://www.thejakartapost.com/life/201 9/01/22/facebooks-whatsapp-limits-users-to-five-text-forw ards-to-curb-rumors.html

[49] Revell, L., \& Arthur, J. (2007). Character education in schools and the education of teachers. Journal of Moral Education, 36(1), 79-92. Retrieved from http://dx.doi.org/1 $0.1080 / 03057240701194738$

[50] Ridwan, A., Rahmawati, Y., \& Hadinugrahaningsih, T. (2017). STEAM integration in chemistry learning for developing 21st century skills. MIER Journal of Educational Studies, 7(2), 184-194.
[51] Riesman, D. (1967). Some Questions about the Study of American Character in the Twentieth Century. The ANNALS of the American Academy of Political and Social Science, $370(1), 36$ - 47.

[52] Risnawati. (2017). The Implementation of Education Character on Moral in MTsN (Islamic Junior High State School) 1 Pontiakan in the Academic Year 2015/2016. Journal of Education and Practice, 8(9).

[53] Rivers, C., \& Kinchin, I. (2018). Dynamic Learning: Designing a Hidden Pedagogy to Enhance Critical Thinking Skills Development. Management Teaching Review, 1-9.

[54] Sanderse, W. (2013). The meaning of role modelling in moral and character education. Journal of Moral Education, 42(1), 28-42. Retrieved from http://dx.doi.org/10.1080/030 57240.2012 .690727

[55] Schaeffer, E. F. (1999). It's time for school to implement character education. Character education.

[56] Shields, D. L. (2011). Character as the Aim of Education. Phi Delta Kappan, 48-53.

[57] Shpeizer, R. (2018). Teaching critical thinking as a vehicle for personal and social transformation. Research in Education, 0(0), 1-18.

[58] Skaggs, G., \& Bodenhorn, N. (2006). Relationships between Implementing Character Education, Character Education, Stucent Behaviour and Student Achievement. Journal of Advance Academics, 18(1), 82-114.

[59] Solihati, N., \& Hikmat, A. (2018). Critical Thinking Tasks Manifested in Indonesian Language Textbooks for Senior Secondary Students. Original research, 1-8.

[60] Stiff-Williams, H. R. (2010). Widening the Lens to Teach Character Education Alongside Standards Curriculum. The Clearing House, 83(4), 115-120.

[61] The Jakarta Post. (2019, January 28). Ahmad Dhani gets 18 months for insulting Ahok supporters. Retrieved from The Jakarta Post: https://www.thejakartapost.com/news/2019/0 1/28/ahmad-dhani-gets-18-months-for-insulting-ahok-supp orters.html

[62] Thompson, T. (2017). Teaching Creativity through Inquiry Science. Gifted Childs Today, 40(1), 29-42.

[63] Turan, F., \& Ulutas, I. (2016). Using Storybooks as a Character Education Tools. Journal of Education and Practice, 7(15)

[64] Tutkun, E., Görgüt, İ., \& Erdemir, İ. (2017). Physical Education Teachers' Views about Character Education. International Education Studies.

[65] Vaccarezza, S. M., \& Niccoli, A. (2018). The dark side of the exceptional: On moral exemplars, character education, and negative emotions. Journal of Moral Education, 1-13. Retrieved fromhttps://doi.org/10.1080/03057240.2018.153 4089

[66] Van Rooij, E. (2018). Secondary school students' university readiness and their transition to university. Doctoral thesis, University of Groningen.

[67] Vessels, G. G., \& Boyd, S. M. (1996). Public and constitutional support for character education. Values and 
Character Education, 55-62. Retrieved from https://doi.org $/ 10.1177 / 019263659608057910$

[68] Wang, S., \& Seepho, S. (2017). Facilitating Chinese EFL Learners' Critical Thinking Skills: The Contributions of Teaching Strategies. SAGE Open, 1-9.

[69] Williams, D. D., Yanchar, S. C., \& Jensen, L. C. (2003). Character Education in a Public High School: a multi-year inquiry into Unified Studies. Journal of Moral Education, 32(1), 3-33. Retrieved from http://dx.doi.org/10.1080/0305 724022000073310

[70] Zein, S. (2016). Pre-service education for primary school English teachers in Indonesia: policy implications. Asia Pacific Journal of Education, 119-134. Retrieved from http://dx.doi.org/10.1080/02188791.2014.961899 